\title{
Responses to violence in some lament Psalms of the individual 1
}

D G Firth

\section{ABSTRACT}

Responses to violence in some lament Psalms of the individual

Lament psalms of the individual that reflect a motif of violence are here examined so as to determine whether or not the editors of the Psalter had a pattern of instruction that they wished to inculcate with respect to the experience of violence. An examination of prayers of the accused and prayers of sickness as sub-groups within the Gattung indicates the presence of such a pattern, and suggests that the editors wished to model a pattern that rejects the right of human retribution. This pattern needs to be tested further through an examination of a third sub-group, the prayers for protection.

\section{A INTRODUCTION}

Amongst a rising interest in the study of the topic of violence in the Old Testament, it has been notable that the perspective of the Psalms has not been considered ${ }^{2}$. The predominance of the form critical method as the means of studying Psalms would perhaps explain this since it has tended to consider the Sitz im Leben of individual psalms rather than that of the book as a whole. It is one of the more significant developments of the canonical method as developed by people like Childs ${ }^{3}$ that the shape of the finished book is now considered. This approach allows us to consider not only the life setting of an individual psalm, but also the role assigned to any such psalm by the final editors of the book of Psalms. The recognition of this fact allows us to approach the book of Psalms to determine whether or not the editors, through their process of selection, have sought to include some form of instruction on the topic of violence. The presence of a consistent pattern in the response to violence within the book would thus suggest that the editors, whether consciously or unconsciously, have a model of response to violence that they considered to be appropriate. The presence of such a pattern would then indicate that it has become a part of the instruction of the book of Psalms. So as to keep the present study within 
manageable boundaries, we shall only consider lament psalms of the individual, and then only two sub-groups within this larger classification.

\section{B DEFINITIONS}

\section{Violence}

A primary issue that needs to be resolved at the outset is the determination of what is meant by "violence" and how we may recognise its presence in the Psalms. We should note that this requires more than the presence of the words שָד terms that describe actions of violence, such as striking, crushing or trampling, are more important for a study of the response to violence. This is because they more closely define the type of action to which we find a response. These terms may indicate a motif of violence when they reflect an unjust or unwarranted use of force. Psalms that have two or more verbs not in parallel reflecting a motif of violence can be considered for this study.

A reader of the Psalms will note, however, that even these sorts of terms are not used in a uniform manner. For example, the verb normally translated "to crush". In Psalm 89:11 it has a clearly physical connotation, describing what Yahweh has done to the sea monster Rahab. This is so irrespective of the mythological background of the language. In Psalm 94:5, however, the same verb is used to describe the actions of the wicked against society. In this context, the physical sense of the verb is being extended to describe an action against the social structure of the nation. This use of the verb has a related, but distinct sense. Finally, in Psalm 143:3 the same verb is used, but the context describes the result of the action of the enemy in terms of a weakening of spirit and heart. In this context, then, the immediately physical sense of the verb is weakened, describing the psychological experience of the psalmist. In all three places, the physical sense of the verb remains, so as to suggest the presence of violence, but the type of violence suggested varies, depending on what the action affects.

This example suggests, then, that violence can be viewed in three different ways, with the type of violence reflected being determined by the different areas of effect. Violence may affect the psalmists physically, as a part of a wider social group, or in terms of their psyche. We may therefore describe these forms of violence as being either physical, social or psychological, though in the case of the latter it needs to be distinguished 
from the way the term is sometimes used within the modern discipline of psychology. In the case of psychological violence we shall note that it is frequently the imminence of physical violence that creates the distress. Such a distinction in the forms taken by violence is also recognised by some contemporary sociologists ${ }^{4}$. It is possible to experience violence that includes more than one of these categories, but one will be primary.

\section{Lament Psalms of the individual}

The Gattung of the lament of the individual is one that is well established in Psalms research 5 . However, the identity of the individual who speaks is less clear, with scholars variously arguing that it is the king, a cultic official or a private individual who speaks in these psalms. Although differing with him on individual psalms, the position taken by $\mathrm{Croft}^{6}$ that allows any of these options to be correct, and thus to be determined on a case by case basis, is surely correct. Again, for reason of the need to keep this study within definable limits, we shall consider only those cases where it would seem most probable that the individual who speaks in the psalm is a private individual.

Although the individual lament is a Gattung that has a certain consistency in and of itself, it is better to see it as an umbrella term that describes a number of different types of complaint. We may note three sub-groups that belong in this Gattung and that also reflect a motif of violence - prayers of the accused, prayers for protection and prayers of the sick. Each of these sub-groups needs to be investigated if we are to determine whether or not there is a standard response to violence within the lament psalms of the individual. The reason for this is that they reflect different contexts in which violence may be experienced. Given, though, that the prayers for protection are a broader group than the others, they will need to be examined in a separate study. Further, a good case can be made for both the prayers of the accused and the prayers of sickness having arisen within the cultic liturgy, something that is less clear for the prayers for protection. The possibility of a transformation of function for these psalms when placed in a non-cultic setting, such as a book, provides some further justification for treating these two together. We must, therefore, now examine the response to violence in the prayers of the accused and the prayers of sickness, although it should be recognised that our conclusions will remain tentative until the prayers for protection can be examined. 


\section{PRAYERS OF THE ACCUSED}

\section{Identification and function}

Four psalms of the individual from this group can be identified as representing a motif of violence - Psalms 7, 17, 109 and 139. Although some interpreters have regarded the "I" in these psalms as the king?, the basis for making such an identification seems ill-defined. In each case, we note that the psalmists seek vindication from Yahweh because of the charges that have been made, asking either that they be declared innocent or their accusers guilty $(7: 4-5 ; 17: 1-2 ; 109: 6-20 ; 139: 23-24)$. The court setting is ill-suited to a royal identification, and an individual interpretation is to be preferred.

Whether or not these psalms reflect a point of cultic origin is less clear. The pioneering essay of Schmidt ${ }^{8}$ took the position that they were to be interpreted in terms of a cultic institution, and he has been followed to some extent by Beyerlin ${ }^{9}$ and Delekat ${ }^{10}$, though neither has followed his categories exactly. Beyerlin does not, however, insist on all these psalms having a cultic point of origin ${ }^{11}$, a view that seems historically more probable. However, the book of Psalms does not present any of these psalms in an overtly cultic manner, and certainly no cultic rubrics are present. It would therefore seem that whatever their relationship with the cult may have been historically, they now have a new instructional function within the book. That is, they model the types of prayers that the editors of the book considered to be appropriate for an individual in the context of accusation, and more specifically false accusation since all of these psalms assume that the accusation is false. The question is then, what kind of instruction is offered? The answer to this can be determined by examining the nature of violence and the type of response offered to it.

\section{Nature of Violence}

It is notable that all four of these psalms reflect a constant pattern in terms of the violence that is experienced. This may be because of the fact that in each case the charge seems to relate to a capital offence. In the cases of Psalms 7, 17 and 109 the violence that is experienced by the psalmist is clearly expressed in psychological terms, and a strong case for this can also be made for Psalm 139.

Although both Psalms 7 and 17 make use of the simile of the lion in describing the actions of the enemy (Psalm 7:3; 17:12), and thus seemingly 
speak of physical violence, the simile itself is applied to the accusation that has been made. This suggests, of course, that physical violence is a very real possibility, but at this stage it remains potential rather than actual. It is this potential for physical violence that causes the current distress, which is therefore psychological.

A similar situation is presumed by Psalm 109. What is slightly different here is that the words of the accusers are already understood as generating distress $(109: 4 \mathrm{f})$. In light of the fact that the charge would appear to be of a capital offence, such a response is readily understandable, though the fact that the accusers are portrayed as former friends (109:5f) would also support such a conclusion. Psalm 139 would appear to operate in similar terms, although the psalmist does not give a direct reference to the violence experienced through the previous activities of the enemies. The experience of violence that is reflected in this group is thus of a predominantly psychological nature.

In spite of this fact, it is also notable that the violence that the psalmists desire to see enacted against the enemies is physical in nature. In Psalm 7:13-17, this is expressed in terms of a wisdom world view which assumes that the actions of enemies who make a false accusation inevitably recoils back on them ${ }^{12}$. Psalm 139:19-21 expresses this in terms of a selfcurse, but one that clearly includes the enemies. In Psalms 17 and 109 this is more directly expressed through a request that Yahweh act with violence against those who have made the accusations (17:13f; 109:6-20). The violence that has been experienced is primarily psychological, but the violence that is desired is physical. Consistently, however, it is notable that what is requested is an application of a law of false accusation, such as that found in Deuteronomy 19:16-1913. The psalmists desire that the penalty that would have been applied to them be applied to their accusers.

\section{Response to Violence}

The response to violence that we note in these psalms thus follows a consistent pattern that is indicative of the instructional value assigned to them by the editors. Although violence is desired in retribution against those who have made the accusations, in no case does the psalmist seek permission from Yahweh to carry out such violence personally. Instead, it was consistently the case that the prayer left the final decision to Yahweh. In Psalm 7, of course, the wisdom world view assumed that Yahweh would bring about justice, so there was no need to ask for permission to go further. The other three did ask for more, but always in submission to 
Yahweh. In an originally cultic situation, of course, a supplicant could do little more. But the inclusion of these psalms in the Psalter moves them out of the cult and into the general life of prayer within the community.

A response of submission to the decision of Yahweh is now modelled as the appropriate response to an accusation. A request for the approval of personal vengeance is not. The editors of the Psalter have thus provided a pattern of instruction on the type of response that should be expected from the faithful in the context of violence generated by false accusation. Although a desire for retribution may exist and should therefore be expressed, it is to be expressed in submission to Yahweh. Even in a situation where this desire is as extreme as that expressed in Psalm 109:6-20, it remains the case that the right to retributive violence is ceded to Yahweh alone. As Brueggemann observes, even the rage that we find here is something that is both submitted to Yahweh and relinquished to him $^{14}$. And that is, in fact, a feature of all four of these psalms, even if they express this in different ways.

\section{PRAYERS OF SICKNESS}

\section{Identification and Function}

The question regarding the identification of prayers of sickness cannot be considered a settled matter in Psalms research. Accordingly, various lists of these psalms tend to differ greatly ${ }^{15}$. For our purposes, a prayer of sickness can be identified if some of the petitions of the prayer relate to illness. On this basis, we can ignore incidental references to illness, and only consider psalms where illness is part of the Sitz im Leben that generated the prayer.

Two psalms of the individual from this group can be identified as representing a motif of violence - Psalms 38 and 69 . As with the prayers of the accused, some interpreters have sought to identify the "I" of these psalms with the king, but the evidence for doing so is not conclusive ${ }^{16}$. Even if these psalms were intended to be royal at some stage of their history, there is nothing in their current context that points unambiguously in that direction. It is accordingly better to regard them as being prayers of a private individual.

Apart from this consideration, there is strong internal evidence to suggest that these psalms are not to be viewed as royal. The enemies in Psalm 38 are clearly private and not national figures, whilst the conclusion to Psalm 69 with its reference to the desire for Jerusalem to be re-built 
must be post-exilic ${ }^{17}$. In neither case, then, does the context of the psalm or its internal evidence point to it being royal.

A further similarity between these psalms and the prayers of the accused is that they too may have had a cultic point of origin. Brown, for example, observes that there "should be no question that the psalms of sickness and healing were utilised with regularity in the temple services in Jerusalem"18. In general, such a point can be sustained. However, as with the prayers of the accused, the placement of these psalms in the Psalter opens up new options for their use. They are no longer bound to whatever cultic procedures may have been followed in the temple. Instead, they have become model prayers for use by the sick. By their inclusion in the finished book, the editors have thus suggested that these psalms become the types of prayer that can be uttered by the ill, and in the case of these two psalms, in the specific situation of the combination of illness and the experience of violence.

\section{Nature of violence}

We shall note that both of these psalms follow a pattern similar to that of the prayers of the accused in terms of the nature of violence experienced and the violence that is desired against the enemies. This seems to be related to the fact that, in terms of the enemies, physical violence is understood as being imminent. Therefore, the experience of violence to which both psalmists testify is of a primarily psychological nature. However, these psalms add an additional dimension in that they both understand the illness to be as a result of the direct action of Yahweh, so that they experience his violence physically ${ }^{19}$.

\section{a) Violence inflicted by the enemies}

The pattern of violence experienced from the enemies in Psalm 38 is outlined in verses 10-17. Two elements become clear in these verses. First, physical violence from the enemies is believed to be imminent. In verse 13, the psalmist refers to those who seek his life laying traps for him, plotting

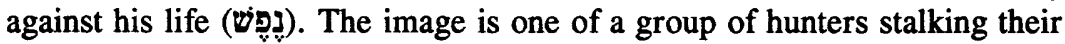
prey. Physical violence is thus seen as imminent, but a second element is introduced in verses 14-15. These verses indicate that this immanence is already having an effect on the psalmist's psyche, making him like a deaf mute ${ }^{20}$. The actions of the enemies, in conjunction with the decision of friends to abandon the psalmist ( $v$ 12), thus creates a deep psychological distress. 
We do not find a direct request for action against the enemies in this psalm. Instead, it builds to a climax in verses $22-23$ by recognising that the psalmist's hope lies in Yahweh alone. Nothing further than this is sought, for it is assumed that if Yahweh shows himself as saviour then the enemies will indeed be overcome.

The experience of violence from the enemies in Psalm 69 is quite similar. Once again, we have a reference to the aim of the enemies in terms of the desire to take the psalmist's life ( $v$ 5). The perceived imminence of physical violence can be reasonably understood as generating psychological distress, and may well reflect the waters that are said to be up to the psalmist's neck ( the enemies are generating psychological distress is seen in the frequent references to the psalmist suffering scorn (חרף, either verbally or nominally, verses $8,20 \& 21$ ) or being insulted (v 10). Thus, instead of finding sympathy, the enemies are portrayed as taking advantage of the psalmist's weakness to inflict further harm (vv 21-22). All of this is related to the psalmist's loyalty to Yahweh, which is why the matter is brought before him.

Unlike Psalm 38, Psalm 69 does ask for direct physical action against the enemies in verses 23-29. What is sought is extreme in that it seeks illness (vv 23f) and then the death of the enemies ( $v$ 29). These elements are, however, precisely what the enemies have brought into the domain of the psalmist's life. Their actions are seen as generating the illness, and their stated aim was the death of the psalmist. What is sought, then, is an application of the lex talionis, for Yahweh is asked to afflict the enemies with what they have sought to afflict the psalmist. The law of retribution thus functions to shape the retribution that is sought. Verse 30 is of great significance here, since it finally asks that it will be Yahweh's salvation that will protect the psalmist, exactly the same as we saw in Psalm 38.

\section{b Violence inflicted by Yahweh}

Although the violence inflicted by the enemies is seen in predominantly psychological terms, the violence inflicted by Yahweh is seen in physical terms. Both psalms reflect a perspective that believes that the illness experienced by the psalmist derives from the activity of Yahweh. In Psalm 38 it is particularly clear that this is understood as an expression of Yahweh's violence since it flows from his wrath and was delivered through his "arrows" ( $v 3$ ). It is a consistent position in the Old Testament that the 
wrath of Yahweh is just when it is expressed, and this is the position adopted by the psalmist who confesses guilt ( $v 5)$ and sin ( $v$ 19). The action of Yahweh against the psalmist is seen in terms of violence, but violence that is just, and that was required because of sin.

The same perspective occurs in Psalm 69, though it is not as fully developed. Once again, the psalmist confesses guilt $(v 6)$, though the relationship between this guilt and the experience of illness is never made explicit. The psalm could be understood as suggesting that the illness was caused by the enemies, but the reference in verse 27 to the enemies' persecution of those whom "you (i.e. Yahweh) wound" would suggest that a balanced position is held. The illness comes about because of Yahweh's physical action against the psalmist and the actions of the enemies. Nevertheless, the decisive difference between them is once again that Yahweh's action is seen as just, but the actions of the enemies are seen as unjust.

\section{Response to violence}

The response to violence in these Psalms therefore needs to be seen in terms of the two different sources of violence. Put simply, the violence that is received from Yahweh through illness is to be accepted as a just expression of his discipline. This does not suggest that the editors saw all illness in these terms, but recognises that they believed this may be the cause in some instances where guilt was a real element. All the violence of Yahweh is seen as being just, and can therefore not be rejected.

On the other hand, the violence enacted by the enemies is seen as unjust. Under these circumstances, it is notable that the pattern of response to the violence is virtually identical to that which we noted in the prayers of the accused. In both Psalms 38 and 69 the psalmist brings the matter before Yahweh. Psalm 38 seems to offer a particularly profound view of the matter in that it assumes that once it has been raised with Yahweh then nothing more needs to be said. Psalm 69 is closer to Psalm 109 in that it asks for specific action against the enemies. As noted, though, this request is shaped by an application of the law of retribution. Where the requests in the prayers of the accused were shaped and limited by the law of false accusation, here they are shaped and limited by the law of retribution. The underlying assumption, though, is that the violence enacted by Yahweh alone is just, and it is on this basis that these psalms also leave the issue of retribution to Yahweh instead of seeking justification for personal retribution. 
These psalms thus also model a response of submission to the decision of Yahweh. In this way, they follow the same pattern of instruction that we noted with the prayers of the accused. A desire for personal retribution may indeed be expressed, but the decision on how and if that retribution is to be enacted is left with Yahweh. Through the presence of this pattern, the editors have once again instructed the faithful on the type of prayer that they considered appropriate in a situation of illness and the suffering of violence. The matter is to be submitted to Yahweh and left at that point, because the violence of Yahweh alone is just. Again, we should note that if these psalms were a part of a temple liturgy they could hardly be formulated in other terms, but the formation of a book of Psalms has once again put them into a broader context. No longer are they limited to the cult, they are now model prayers for all the faithful.

\section{E CONCLUSION}

The presence of a consistent pattern in these psalms is suggestive of the fact that the editors of the Psalter wished to indicate a certain type of response to violence as being normative for the faithful. This response was one where the right to retributive violence was not something that the worshipper could claim. Nor could the worshipper ask that Yahweh initiate unlimited retribution against the enemy, for there are very clear limits on what can be sought. Instead, the whole context of violence is to be submitted to Yahweh, and left at the point of submission. Individual retribution is ruled out.

It is to be noted that these psalms do not, of course, indicate how it is that Yahweh will respond to the requests of the faithful as they face a context of violence. That, however, is not the purpose of the editors in the instruction that they offer. What they are seeking to do in these psalms is to inculcate an attitude, an attitude that is to be reflected in the prayers of the faithful. And that attitude is one of dependence upon Yahweh and his justice alone.

\section{NOTES:}

1 This paper is a summary of a $\mathrm{Ph} \mathrm{D}$ thesis that was submitted in the department of Old Testament, Faculty of Theology, University of Pretoria with professor W S Prinsloo as promotor. 
2 Cf the Forschungsgeschichte by $\mathrm{N}$ Lohfink, "Gewalt als Thema alltestamentlicher Forschung”, in: N Lohfink (ed), Gewalt und Gewaltlosigkeit in Alten Testament, Freiburg 1983, 15-50.

3 Brevard S Childs, Introduction to the Old Testament as Scripture, London 1979, especially $511-522$.

4 Cf D P Whitelaw, "Christian responses to violence: A historical survey", in: W Vorster (ed), Views on violence, Pretoria 1985, 24.

5 Cf Hermann Gunkel, The Psalms: A Form Critical Introduction, Philadelphia $1967,19 f f$.

6 Steven J L Croft, The Identity of the Individual in the Psalms, Sheffield 1987.

7 For example, John H Eaton, Kingship and the Psalms, London 1976, argues that Psalms 7 and 17 are clearly royal, whilst Psalms 109 and 139 could be royal.

8 Hans Schmidt, Das Gebet der Angeklagten im Alten Testament, Giessen 1928.

9 Walter Beyerlin, Die Rettung der Bedrängten in den Feindpsalmen der Einzelnen auf institutionelle Zusammenhänge untersucht, Göttingen 1970.

10 L Delekat, Asylie und Schutzorakel am Zionheiligtum: Eine Untersuchung zu den privaten Feindpsalmen, Leiden 1967.

11 Cf also W H Bellinger Jr, Psalmody and prophecy, Sheffield 1984, 33.

12 Textual difficulties with verse 13 make it difficult to decide whether this wisdom world view is first introduced here or at verse 15 . Although A A McIntosh, "A Consideration of Psalm 7:12f", Journal of Theological Studies 33(1982), has argued that verse 13 refers to God and not the enemy (cf also NIV), the opening לx would seem to introduce an asseveration dealing with a new point of reference. Cf Hans-Joachim Kraus, Psalms 1 - 59, Minneapolis $1988,174 f$.

13 The dating of the text of Deuteronomy does not affect this point. The fact is that all these psalms assume a law that is essentially the same as the one found in Deuteronomy. On the antiquity of the material that is found in Deuteronomy, cf J Gordon McConville, Grace in the end, Carlisle 1993, 45-64.

14 Walter Brueggemann, The message of the Psalms, Minneapolis 1984, 85.

15 Cf Michael L Brown, Israel's divine healer, Grand Rapids 1995, $121 \mathrm{f}$.

16 Eaton, op cit, 51ff, regards Psalm 69 as "clearly royal", but discounts any association between Psalm 38 and the royal rites. Conversely Croft, op cit, $117 \mathrm{f}$ 
\& 128f, regards both psalms as being royal. Their basic disagreement is illustrative of the problems associated with identifying royal psalms.

17 The integrity of the concluding verses is often questioned. However, Leslie C Allen, "The value of rhetorical criticism in Psalm 69", Journal of Biblical Literature 105/4 (1986), 577-598 and J H Coetzee, Die spanning tussen God se "verborge wees" en Sy "ingrype om te red". 'n Eksegetiese ondersoek na 'n aantal Klaagpsalms, Unpublished DD Thesis, University of Pretoria 1986, 170, have both demonstrated good grounds for accepting the integrity of the psalm as a whole. However, even if the final verses are an addition to the text, they would indicate that it now functions as a psalm of a private individual.

18 Brown, op cit, 154.

19 Fredrik Lindström, Suffering and sin: Interpretations of illness in individual complaint Psalms, Stockholm 1994, argues that these psalms did not originally contain the elements attributing the illness to Yahweh. Even if we accept his argument, and it seems to require some special pleading in that all instances texts that make the claim are treated as later additions, our basic observation holds good for the instruction of the Psalter. The texts available to the editors include this element, and are therefore a part of their instruction.

20 Kraus, op cit, $412 \mathrm{f}$, believes that this is feigned. This is certainly a possible way of reading the Hebrew, though it would perhaps require that the verse be scanned as $2+2+3$. But Willem van Gemeren, "Psalms", in: The Expositor's Bible Commentary vol 5 (Edited by Frank E Gaebelein), Grand Rapids 1991, 310, is more likely to be correct in seeing it as an expression of intense loneliness. 